\title{
Higher Education Institutions: Decisive Players for Cross-border Integration
}

\section{As instituições de ensino superior: Atores decisivos na integração fronteiriça}

\author{
Francisco Javier Llera Pacheco \\ Angeles López-Nórez \\ Universidad Autónoma de Ciudad Juárez, México
}

\begin{abstract}
The purpose of this article is to compare how Cross-border Collaboration (CBC) is being conducted between Universities in the border twin cities of Ciudad Juarez/El Paso and Frankfurt (Oder)/Slubice. Both areas concentrate Higher Education Institutions (HEIs) facing the similar challenge of pursuing collaboration within a context characterized by unequal economic development and influenced by supranational structures, such as the North American Free Trade Agreement and the European Union, respectively. As a result of the comparison of some of the CBC initiatives that have been conducted between HEIs in the study areas, the document points out that the development of knowledge societies in border regions requires the existence of a mature $\mathrm{CBC}$ culture among the local community.

Keywords: Cross-border collaboration. Higher education institutions. Economic development. Knowledge societies.

Resumo: O propósito deste artigo foi comparar como se realiza a colaboração transfronteiriça entre as universidades das cidades irmãs de Ciudad Juárez / El Paso, na fronteira entre México e Estados Unidos, com Frankfurt (Oder) / Slubice, na fronteira entre Alemanha e Polônia. Ambas as regiões tem Instituições de Ensino Superior (IES) que enfrentam desafios semelhantes para manter colaboração em um contexto de desenvolvimento econômico diferenciado e que tem sido influenciado por estruturas superiores, como a Nafta e a União Econômica Européia, respectivamente. Como resultado da comparação de algumas das iniciativas de colaboração transfronteiriça que se tem desenvolvido entre as IES nas áreas de pesquisa, enfatiza-se o desenvolvimento de sociedades de conhecimento na fronteira, o que requer a existência de uma cultura de colaboração transfronteiriça madura com a comunidade local.
\end{abstract}

Palabras clave: Colaboração transfronteiriça. Instituições de ensino superior. Desenvolvimento econômico. Sociedades de conhecimento. 


\section{INTRODUCTION}

The patterns of economic integration experienced by the society worldwide have introduced new demands and requirements both to the local Higher Education Institutions (HEIs) and to the local communities. These demands mostly imply to educate competitive students that may contribute with the progress of local regions. In the new global society, HEIs are being considered not only responsible to prepare competitive students but also responsible to produce knowledge societies and knowledge economies. In other words, sciences applied not only to generate high skilled human resources but also to contribute on the creation of spaces and sources for the development of those resources. The process, then, is not concluded within the educational cycle, but with the participation of HEIs in the process of job creation and economic diversification of the localities where they are established. This tendency is starting to become particularly influential within HEIs worldwide. Notwithstanding, the outcomes and adaptation of such institutions to this process have been of dissimilar magnitude and rhythm in the different regions of the world. Particularly, in border regions, where the coexistence of two national contexts experiencing regional differences in diverse fields such as educational policies, economic resources and technological infrastructure represents considerable barriers for HEIs to produce bi-national knowledge societies and knowledge economies (BATTERBURY and HILL, 2004).

The purpose of this empirical research is to compare how Cross-border Collaboration (CBC) is constructed between HEIs interacting in border twin cities of the American/Mexican and the German/ Polish border contexts. In border regions it is difficult to envision the production of knowledge societies and knowledge economies only in one side. In this work, it is argued that the production of knowledge societies and knowledge economies in twin border cities is not feasible if there is an absence of systematic strategies for $\mathrm{CBC}$. Based on the above hypothesis, the comparative study of CBC between HEIs in border localities is relevant since these institutions might be the actors with more expertise in conducting CBC initiatives in such areas. These academic experiences could become the basis to develop systematic and permanent governmental strategies for CBC in border regions. These are indispensable conditions to achieve a bi-national long term vision, to create regional economic growth based on the retention of high educated people, and to cultivate knowledge societies in border regions.

\section{THEORETICAL FRAMEWORK AND RESEARCH METHODOLOGY}

This article considers CBC as a comprehensive process of relationships between border partners interested to complement each other, to produce outcomes that are related to the development of the region, and that might help to reduce regional inequalities in some degree. This process can be studied either from a formal or an informal perspective and based on multidisciplinary and methodological approaches. From a formal perspective, the analysis focuses on institutional actions. From an informal perspective, the analysis focuses on outcomes produced by the social and cultural context. In this research work, CBC between HEIs will be studied from both perspectives. These perspectives have been organized in two general components: attachment and willingness. Together, attachment and 
willingness are the result of the interaction of seven indicators (Figure 1). The intention of constructing this model is develop a theoretical scheme that would help to conduct systematic comparative research in border regions. This theoretical scheme has been enriched by border literature that has sought to explain cooperation among border communities worldwide (BLATTER, 2004; GRIX, 2001; KRÄTKE, 2002; LEIBENATH, 2007; MARTINEZ, 1994).

Graphic 1 - Model to compare Cross-border Collaboration

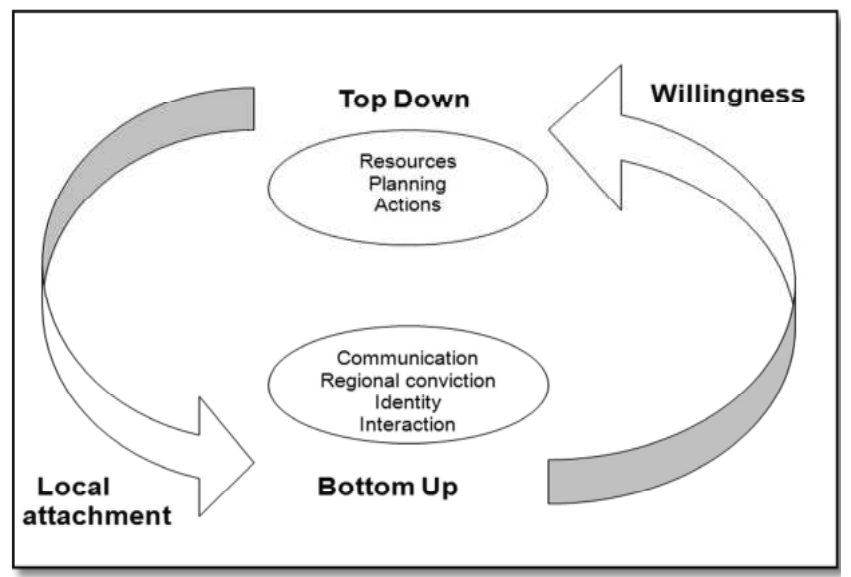

Source: Based on ideas of Blatter, 2004; Grix, 2011; Krätke, 2002; Leibenath, 2007 and Martinez, 1994

The first component of analysis is willingness. Willingness is a top-down component that emerges from formal organizations interested to become implicated in common bi-national activities. In this research, willingness is studied through three indicators: planning, resources, and actions. Planning is relevant because it constitutes the base to develop a shared vision. Nevertheless, in border regions, the main constraint for institutional bi-national planning at the local level is that it is usually influenced by national and supranational agencies (BLATTER, 2004; KR ÄTKE, 2002; LEIBENATH, 2007). Therefore, it is relevant to pay attention to how planning is being executed and what are its impacts. Willingness for CBC is also perceived through the allocation of resources that contribute to materialize common goals. The study of the sources and the amount of resources addressed for CBC allow identifying how feasible is such process in any particular border region. Finally, actions might be the measurable outcome of willingness and the aspect that should be studied is if they are embedded by a short term or a long-term vision within the different initiatives of CBC.

The second component is attachment. Attachment is defined as a bottom up process related to linkages that develop spontaneously among local actors on both sides and that provide social coherence to cross-border projects and actions. Attachment is present if the process of CBC encompasses four indicators: communication, regional conviction, local identity and interaction (GRIX, 2001; MARTINEZ, 1994). Communication is one of the most significant indicators in this research. In border regions, differences in language traditionally constraint $\mathrm{CBC}$ since a small percentage of the local residents speak the language of the neighbor country. Language differences played an important role to establish agreements, to overcome controversies and to develop trust because it depends on how much information border actors exchanged (GRIX, 2001). A second element to study is interaction. Interaction is a temporal activity that takes place between border partners. It develops naturally from physical proximity. Interaction by itself is not sufficient to produced CBC, but it is an indispensable factor to initiate actions. Interaction is reinforced by the sense of local identity. The sense of local identity is the interest of the population to be recognized as "borderlanders" or inhabitants of the border (MARTINEZ, 1994). This characteristic is nurtured by 
sharing historical, political, economical and social events and traditions. Studying the sense of local identity among border inhabitants is relevant because the interest of the population to remain in the region makes borders desirable places to live and to invest. This element might be the basis for border competitiveness. The final indicator is regional conviction. Regional conviction is the confidence of any organization, whether public or private, national or supranational, to become involved in joint projects and to address human, material, economic and political resources to achieve common goals. Overall, neither willingness nor local attachment alone will suffice for the construction of CBC. This is a circular process rather than a vertical one, and therefore needs periodical evaluation to identify the degree of evolution of such cycle since each of its indicators present different degrees of development in each border region. To contrast the evolution of this process, it is desirable to compare $\mathrm{CBC}$ initiatives from different border regions in periodical terms.

In this empirical work, four HEIs from the North American and Central European contexts were chosen. Research activities were conducted simultaneously in the border twin cities of Ciudad Juarez/El Paso $^{1}$, and Frankfurt (Oder)/Slubice. ${ }^{2}$ Two close-ended surveys were prepared in order to obtain quantitative data from academic leaders and community leaders. One applied to academic leaders and the other to economic leaders and public officials from the four cities. Ten closeended surveys were applied in each city. In addition, interviews with community leaders were conducted. Data collection in the Ciudad Juarez/El Paso was conducted by the research team between August and November 2009, and in the Frankfurt (Oder)/Slubice between January and April 2010. Field research activities were conducted by students and professors from the Universidad Autónoma de Ciudad Juárez, Mexico, as well as from the Christian-Albrechts-Universität zu Kiel, Germany (Figure 2).

Graphic 2 - Data collection method

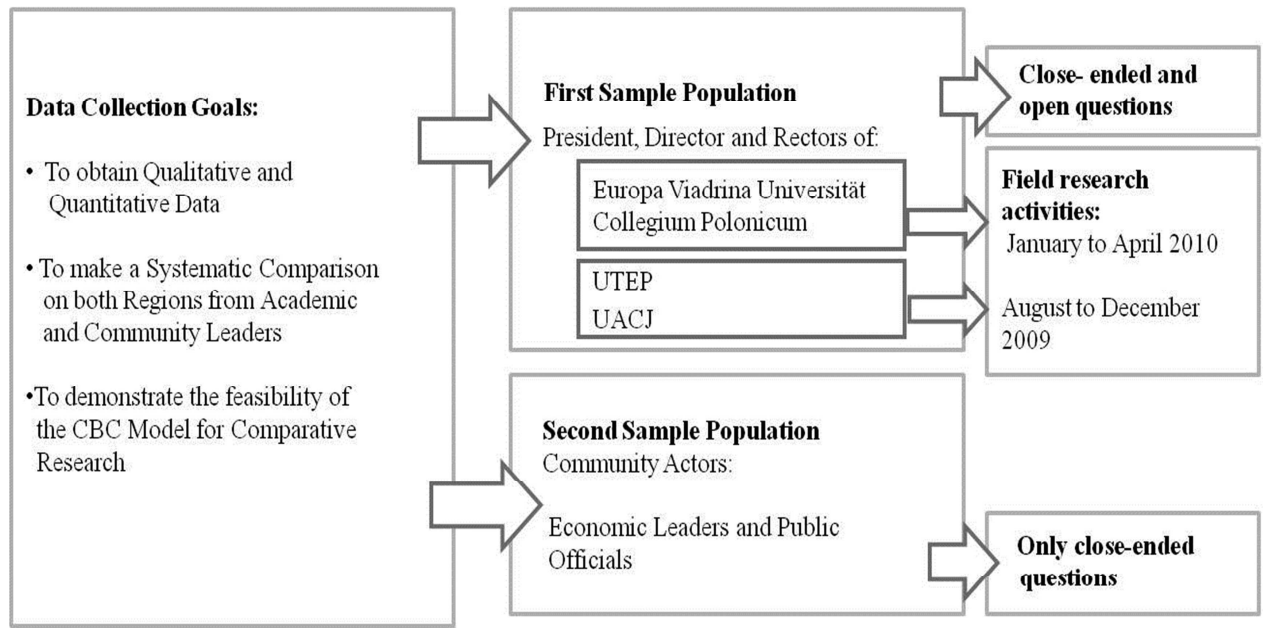

Source: Self-prepared by the authors and based on field research activities conducted by students and professors from the Universidad Autónoma de Ciudad Juárez, Mexico and Christian-AlbrechtsUniversität zu Kiel, Germany

${ }^{1}$ Referred in this document as Paso del Norte.

${ }^{2}$ Referred in this document as Oder region. 


\section{CBC AND HEIS IN THE CIUDAD JUAREZ/EL PASO AND THE FRANKFURT (ODER)/SLUBICE BORDERS}

Formal CBC among HEIs is a relatively recent process on the USA/Mexico and the Germany/Poland borders (Figures 1 and 2). On the one hand, in the Paso del Norte the process of collaboration among HEIs began its formal stage of maturity in the early 1990's as a result of the North American Free Trade Agreement (NAFTA), and the subsequent changes this agreement brought to the Public Policies of
Canada, USA and Mexico. In this twin city region, the University of Texas at El Paso (UTEP) and the Universidad Autónoma de Ciudad Juárez (UACJ) are the two largest public universities. The UTEP was established in 1914 and currently it encompasses an estimated student population of about 20,154 students. It is estimated that about $73.56 \%$ of the total students in this University is of Hispanic heritage and 9\% are Mexican students. This institution offers about 80 undergraduate programs and more than 84 graduate programs (UTEP, 2010).

Figure 1 - The Ciudad Juarez/El Paso region

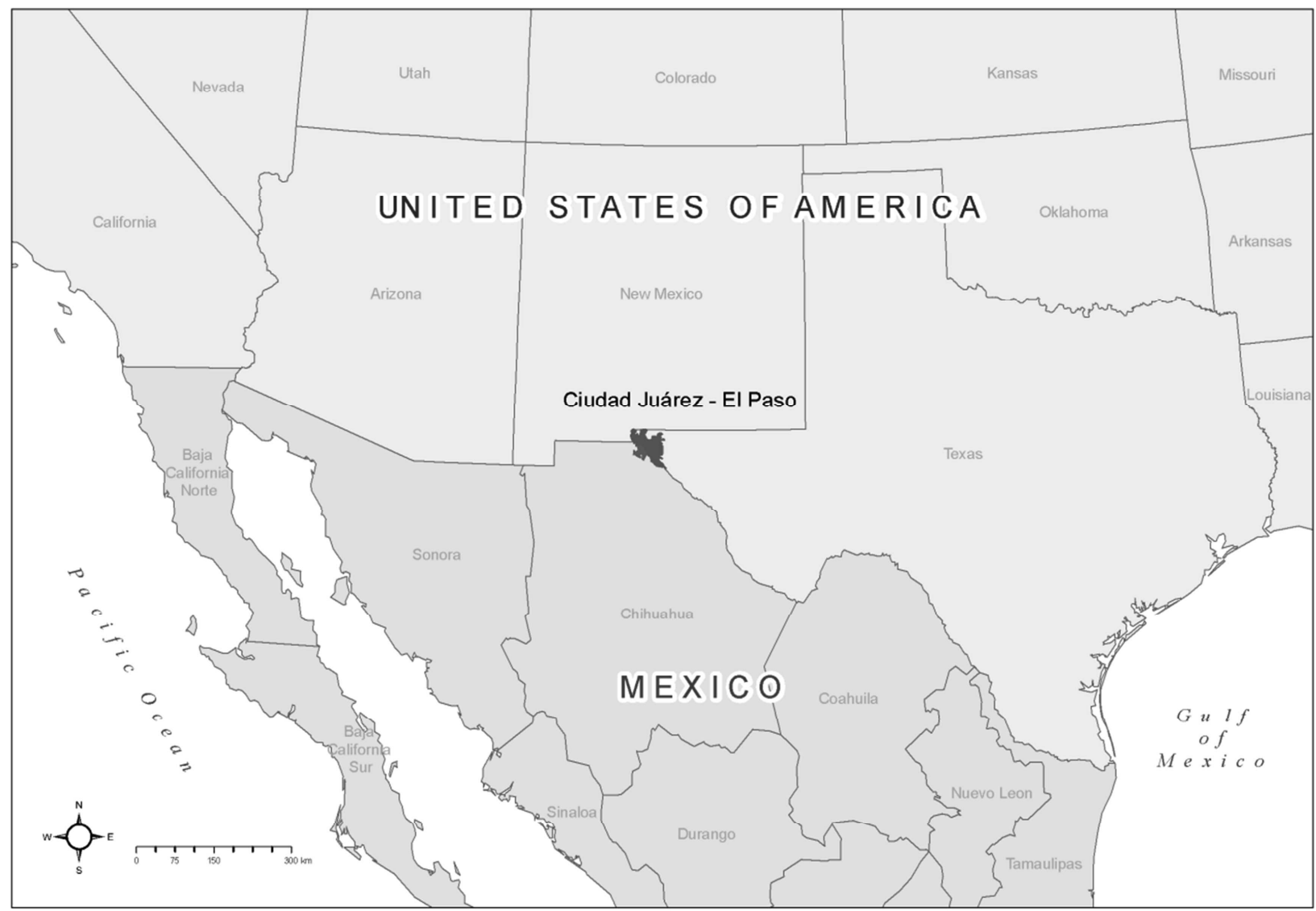

Source: Prepared for this article by Nora Reyes and Dr. Erick Sànchez Universidad Autónoma de Ciudad Juárez 
Figure 2 - The Frankfurt (Oder)/Slubice region

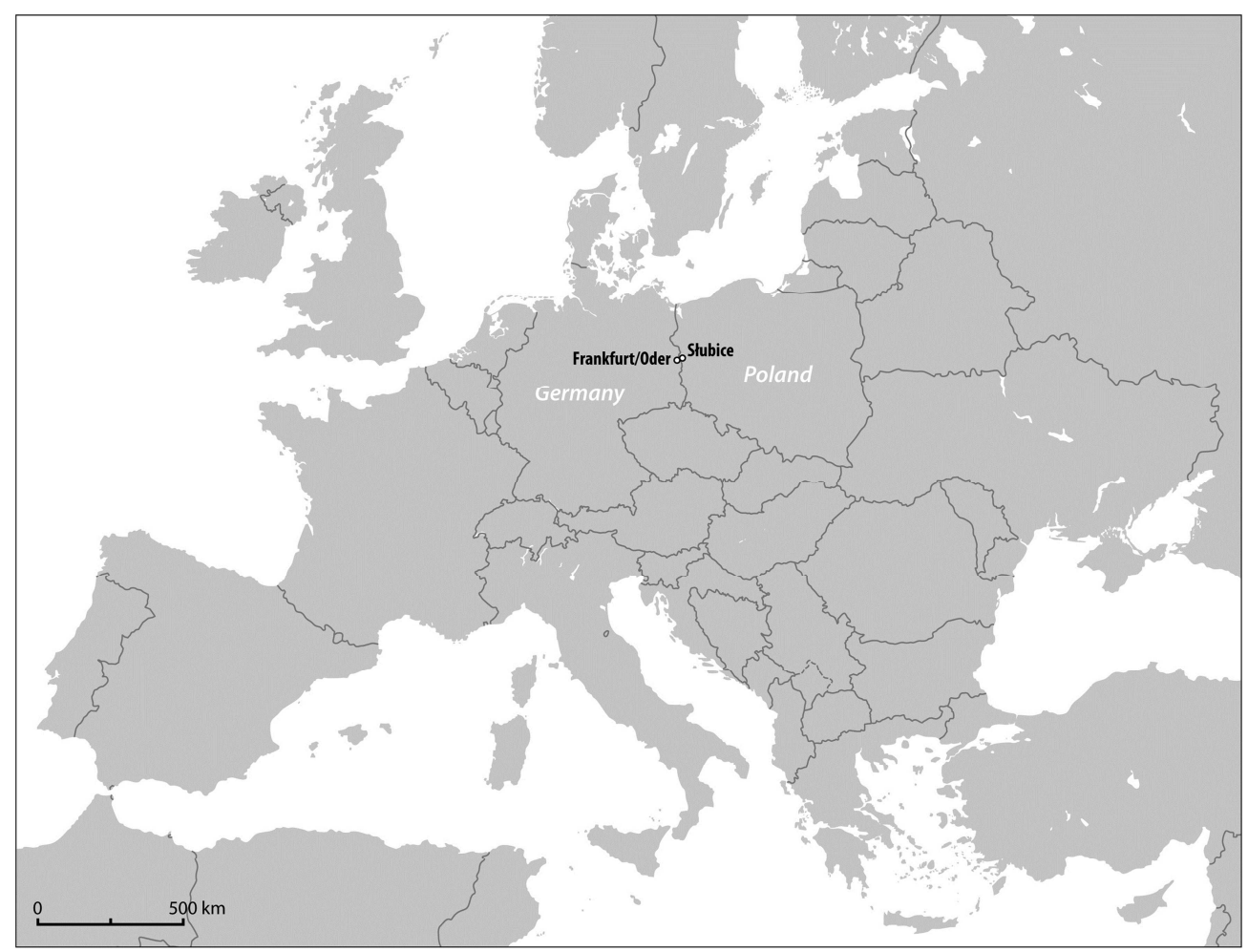

Source: Prepared for this article by Volker Schnniepp. Geographisches Institut, Ruprecht-Karls-Universität Heidelberg.

In the Mexican side, the UACJ is a relatively new institution in the region. It was established in 1973 and has an estimated student population of about 21,221 students. This University has less than $1 \%$ enrollment of American students and offers about 40 undergraduate programs and 48 graduate programs (UACJ, 2010). The different period of creation and the different educational models under which these institutions were created have produced a natural asymmetry between both Universities. Since its origins UTEP has incorporated research and teaching as its basic Educational Model. On the contrary, UACJ emerged as a teaching University with faculty members that mostly lacked graduate education and research skills. This divergence conducted to a limited interaction between both institutions. Language differences among faculty members and students also contributed to increase the asymmetry.

On the other hand, Higher Education collaboration in the current German/ Polish border context is a relatively contemporary process that could be studied since the German reunification in the early 1990's. In the Oder region, the Europa-Universität Viadrina (EUV) and the Collegium Polonicum ${ }^{3}$ are the two most relevant local HEIs. EUV was first establish in 1506 and then re-established in 1991. Currently, EUV has an estimated student population of 6,194 students being $24 \%$ of them foreign students. Before the incorporation of Poland into the EU the percentage of Polish students at EUV reached about $35 \%$. This institution offers 7 undergraduate programs and 19 graduate

\footnotetext{
${ }^{3}$ For the purpose of this research, the Collegium Polonicum will be considered as the partner institution in the Polish side. Notwithstanding, this institution belongs to both EuropaUniversität Viadrina and Adam Mickiewicz University Poznań.
} 
programs. The Collegium Polonicum (CP) is the result of cooperation between the German EUV and the Polish Adam Mickiewicz University Poznan (AMU) and was established in 1998. Students at CP are enrolled either at EUV or at AMU. Currently, the population taking classes at $\mathrm{CP}$ is of about 1,700. Fifteen percent of the total students are foreign. It is estimated that about 700 of them are bilingual students taking classes in German and Polish. In this institution AMU offers 6 undergraduate programs and 2 graduate programs. Together, EUV and AMU offer 4 shared programs (COLLEGIUM POLONICUM, 2009, EUROPA-UNIVERSITÄT VIADRINA, 2010a; WOJCIECHOWSKI, 2010).

The study of CBC between HEIs on both study areas can be better understood through the analysis of their initiatives in terms of two components: willingness and local attachment. The analysis of willingness implies the analysis of the top down institutional policies followed by the HEIs in their efforts to interact with its neighbor. Common planning is the first element to measure willingness. In terms of common planning, it is necessary to consider the external and internal factors influencing the decision making process within HEIs in order to understand how far they can reach in their purposes of $\mathrm{CBC}$. The internal factors influencing the development of a mature common planning process for $\mathrm{CBC}$ between HEIs are the similarities in the administrative terms of University leaders (Presidents or Rectors) and the development of common institutional plans to define short and long term goals and mechanisms of evaluation. External factors influencing the development of common planning between HEIs on both sides of the border are contingent upon the macro and micro conditions experienced by the border localities.
In the Oder region, there has been continuity in the institutional planning process. In this region, the period of common interaction between AMU and EUV at CP encompass 12 years of relationships. During this period, there have been three University Presidents at AMU and EUV and one Director at CP (EUROPA-UNIVERSITÄT VIADRINA, 2008; AMU, 2010). The concordance in the administrative terms of these academic leaders has provided continuity to the cooperation process during the time they have been in office, i.e., since at least six years. Notwithstanding, there still exists a gap to develop a comprehensive and long term plan for the conduction of their bi-national efforts. On the contrary, in the Paso del Norte internal factors affecting common planning between HEIs are the differences in the type of leadership and administrative terms. Since 1973, when UACJ was established, there have been 8 Rectors with diverse administrative terms. Moreover, even when some changes have been experienced during the last 12 years, traditionally Rectors at UACJ have given more attention to develop national rather than international networks. Both factors - the differences in administrative terms and in the direction to construct academic networks - have been fundamental to impede the development of a common vision and the continuity of common efforts with UTEP. To illustrate, during the last 20 years UTEP has only had one University President while UACJ has changed four University Rectors (UTEP, 2010). Under these circumstances, long term planning is very difficult and innovative strategies should be developed by both institutions to overcome this barrier.

Common planning between HEIs is also influenced by external political and economic factors in the Oder region. The incorporation of Poland into the 
European Union has facilitated political negotiations and accessibility to European funding. This has enhanced the planning processes and increased the number of joint academic actions (EUROREGION PRO EUROPA VIADRINA, 2001). The situation is different in the Paso del Norte, where the crime rates and the lack of safety experienced by the Mexican side have made difficult the physical interaction among students and faculty members from both UACJ and UTEP. These external challenges are forcing a change in the adoption of strategies for academic cooperation. The current problem of public safety will force UACJ and UTEP to rely on technology to nurture Academic $\mathrm{CBC}$ for the long term. In this region, recent studies conducted by the OCDE with HEIs have recommended the need of regional planning (HemerotecaDigital@ Juarez, 2009). This might be a sound recommendation, but it is nevertheless unhelpful to impact the development of the border if such planning process is disconnected of the elaboration of a comprehensive bi-national plan for the development of the border.

Another element for willingness is the allocation of resources. In the Oder region, the allocation of human, economic, political and material resources specifically dedicated to strengthen $C B C$ is unquestionable. In this effort, both HEIs and governmental institutions demonstrate the same compliance. The investments of 40 million Euros on each side of the border for the construction of the $\mathrm{CP}$ illustrate such compromise (WOJCIECHOWSKI, 2007a). In addition, at the CP, AMU and EUV have dedicated 45 permanent faculty members each and they share salaries of 44 administrative employees (KLODNICHI, 2010). Moreover, the participation of AMU, EUV, the Federal State of Brandenburg and the Frankfurt (Oder) Employment
Office to fulfill the estimated $€ 800,000$ annual budget of the $\mathrm{CP}$ reflects both the institutional compromise between the HEIs to allocate resources for $C B C$, and the political compromise assumed by the regional governments to foster bi-national initiatives (WOJCIECHOWSKI, 2007b). On the other hand, in the Paso del Norte UACJ and UTEP have focused their resources in technological infrastructure rather than in common physical infrastructure. As part of a Bi-national Educational Strategy to improve the academic connectivity among HEIs on both countries, in 2005 UTEP and UACJ established the first-ever universityowned fiber optic connection between USA and Mexico. This infrastructure allows high speed connectivity with the INTERNET2 international community and with 78 Mexican HEIs (INTERNET2Cases, 2005). This initiative has turned UTEP and UACJ into one of the three most important connectivity bridges to connect Mexican and USA Universities through INTERNET2. These efforts seems to be consistent with the vision of Altbach and Knight (2007), which have expressed that the current patterns of global integration demands to relay more in technology than in physical interaction. Unfortunately, in terms of human and material resources the special allocation of them to provide continuity and to develop innovative academic CBC initiatives is still a missing element.

Actions are the visible outcomes to demonstrate willingness for $C B C$. In the Oder region $\mathrm{CBC}$ between HEIs is observed in material and academic actions. The edification of the $\mathrm{CP}$, with the purpose to develop cooperative research and academic teaching, is perhaps one of the most important material actions in terms of CBC worldwide not only for the amount of economic resources required to build such infrastructure, but also for 
the political agreements among different governmental levels to reach such goal. To illustrate, CP has been considered the second-largest public construction project during the period 1995-1999 in Poland (EUROREGION PRO EUROPA VIADRINA, 2001). Regarding academic actions, $\mathrm{CBC}$ is seen with more maturity in the field of teaching than in joint research activities. Based on the common physical infrastructures at $\mathrm{CP}$, both AMU and EUV offer in a jointly design the Bachelor and Master of German and Polish Law, and Master of European Political Studies. In addition, within the $\mathrm{CP}$, AMU offers six bachelor level programs, and four specialization programs at the postgraduate level. Meanwhile, EUV offers four master programs. There are, however, difficulties in terms of joint research, since faculty members located at the $\mathrm{CP}$ can not apply for research money using this institution as their center; research money for bi-national projects comes either through EUV or AMU (KLODNICKI, 2010). This situation seems to represents one of the institutional constraints to increase the development of joint research projects. Other constraint might be the difference in personal priorities among faculty members. A large number of them are commuters that move frequently either to Poznan or to Berlin reducing their time to develop common research projects.

In the Paso del Norte cross-border academic actions are related to research projects and few joint teaching programs. The joint bachelor program in Physics, established for a short period of time in 1998, and the master program in Health Promotion created in 2005 are good examples of cooperative teaching initiatives. On the other hand, joint academic research has been one of the most successful initiatives in this border since such activities do not require complex institutional arrangements, are flexible, and relay on mutual interest to develop academic networks among researchers. To illustrate, between 2000 and 2006, researchers from both institutions conducted about 14 joint research projects (UACJ-DGIC, 2006). In such process, cross-border researchers have learned to organize themselves in order to coordinate and integrate their efforts based on the existent research funding. $\mathrm{CBC}$ in academic research has been more comprehensive designed, target-oriented and joint developed than teaching programs. The coherence of the academic research agenda between UACJ and UTEP has been based on the interest of American funding institutions to conduct research on share-border problems from a bi-national perspective.

The second component to develop CBC between HEIs is local attachment. Local attachment is nurtured by three elements: sense of local identity, regional conviction and communication. The sense of local identity is only possible if the community has local roots or well-being in the region. On both EUV and CP the detachment of the academic community to the region is to a great extent a consequence of the commuting factor. On the one hand, in the German side, a significant number of students and professors live in Berlin and commute to Frankfurt (Oder) to conduct their activities at EUV (SCHUNOW, 2010). On the other hand, in the Polish side the commuting factor is strongly observed among professors which travel from Poznan to Slubice to work at the CP (KLODNICKI, 2010). This factor is affecting integration since the academic community barely develops networks and interests to remain longer in the region. In the Paso del Norte the sense of identity exists because most of the local academic community belongs or has been in the region for a long 
time. In this border, HEIs majorly receive students from localities surrounding both cities and professors barely commute from other regions. It is common for faculty members and students to become involved in research projects addressed to fulfill local needs. The fact that most of the students are from close localities also contributes to increase their interest to participate in local projects. However, there seems to be a fragmentation between the preparations of high-skilled human resources and the capability of the region to profit from them. To illustrate, in 2001 there were about 772 doctoral students out of a total graduate population of about 3,808 students in the three largest Universities located in the Paso del Norte: UACJ, UTEP and New Mexico State University at Las Cruces (LLERA, 2001). However, a small percentage of them stayed in the region since there were few labor options for high-skilled human resources. In general, it seems that the urgent challenge on the Paso del Norte and the Oder region is the design of a bi-national plan for regional development. This is necessary to mature the sense of local identity among professors and students. The design of a common plan between HEIs and their border communities may contribute to reach a common development vision for the border and to coordinate academic initiatives and public policies. This may contribute to reduce the current pattern experienced by the HEIs on both study areas, which are mainly using the local public resources to educate people for other regions.

One more element to develop local attachment is the existence of regional conviction. Regional conviction is related to the confidence to become involved in joint projects and to achieve common goals. The main barrier to mature regional conviction between HEIs on both study areas is the absence of a long term development vision. In the Oder region, a Bi-national Local Action Plan is still in the process of approval. This plan considers taking advantage of the international image of EUV and CP to promote the region as an international study center (BAUDAUF, 2008; GLEISENSTEIN, 2010). However, it is not clear what strategies will be followed to retain the local high-skilled resources in the region and in what areas they will contribute to enrich the economic development of the region. In the El Paso del Norte local strategic plans in each city envision different goals. Both plans have barely incorporated the strengths and weakness of their local HEIs as a means to encourage bi-national progress. There is also a lack of bi-national vision. Therefore, the problem in terms of regional conviction is the absence of direction to conduct joint academic initiatives. Survey results in this research display the commitment and challenges of the local academic leaders to continue developing projects together. However, there seems to be an absence of common vision and of coordination to establish binational goals for the short and medium term. To illustrate, when academic leaders were asked about future CBC initiatives results displayed differences in interests. On the one hand, UACJ expressed interest in developing joint graduate programs, while UTEP expressed interest to promote bi-national academic activities related to student mobility. On the other hand, EUV expressed interest to address their efforts toward strengthening joint academic programs and increasing joint research at $\mathrm{CP}$, while in the Polish side the $\mathrm{CP}$ expresses interest to address their efforts only in joint teaching projects. Based on such results, one could argue that the absence of a common bi-national academic vision constraints the development of 
long-term $\mathrm{CBC}$ initiatives among HEIs in border regions.

The last element to achieve local attachment is the process of communication. Communication among administrative areas is perhaps the most important challenge to overcome for HEIs in the Paso del Norte and the Oder region. On both regions, survey results displayed that the academic leaders consider this aspect as one of the most difficult barrier for CBC. One reason to explain such barrier might be related to the reduced number of administrative personal to speak the same language of their partners in the other side of the border. The situation is less difficult among students and professors. The development of flexible strategies - such as offering joint programs on both German and Polish and the introduction of English as a third language in which joint programs can be offered - has been of benefit to overcome language differences between EUV and CP (EUROPA-UNIVERSITÄT VIADRINA , 2010b). In the Paso del Norte language differences are overcome by the large number of professors and students speaking Spanish at UTEP and the increase of Mexican professors speaking English at UACJ. On the one side, at UTEP $73 \%$ of the students have Hispanic roots and a large number of professors also have Hispanic heritage (UTEP, 2010). On the other side, at UACJ, as a result of the allocation of economic resources to enlarge the number of professors with graduate education, more than $10 \%$ of the current full-time professors are now able to conduct joint academic activities with their English speaking counterparts (PROMEP-UACJ, 2010). This situation is reflected in terms of Academic CBC between UACJ and UTEP, where it seems more frequent to find American and Mexican partners speaking English and Spanish in their academic activities. Notwithstanding, as mention above, it seems that the differences in communication among administrative areas, if not adequately dealt with, might be one of the aspects that could take the process of CBC toward a stage of stagnation.

\section{CONCLUSION}

The analysis of the relationships developed by HEIs coexisting in the Paso del Norte and the Oder region display that on both areas there has been a gradual process of evolution from border interaction to cross-border collaboration. This evolution has been experienced differently on both border regions (see Table 1). CBC between UACJ and UTEP relays in initiatives where there exists a predominance of elements such as local identity, interaction and resources. To this respect, flexible cross-border initiatives based in personal networks and addressed to resolve common problems of the region dominate in their collaborative actions. Particularly, the most matured level of collaboration is seen in the development of common research projects. CBC between EUV and AMU display predominance of resources and common planning since they have integrated efforts at the CP to develop joint academic programs, to offer academic programs in various languages, to allocate faculty members from both Universities and to provide salaries for administrative personal. Cross-border collaboration between EUV and AMU exhibit less maturity in elements such as regional conviction, sense of local identity and administrative communication. 
Table 1 - Comparative results for Cross-border Collaboration (CBC) between Higher Education Institutions (HEIs) in the study areas.

\begin{tabular}{|c|c|c|c|}
\hline \multicolumn{4}{|c|}{ Higher Education Institutions (HEIs) } \\
\hline Components & Facts & UACJ/UTEP & EUV/CP \\
\hline \multicolumn{4}{|c|}{ Local Attachment } \\
\hline Interaction & Faculty Members & $\begin{array}{l}\text { Education Degree } \\
\text { and Expertise }\end{array}$ & $\begin{array}{l}\text { Commuting Patterns and } \\
\text { Personal Priorities }\end{array}$ \\
\hline \multirow{2}{*}{$\begin{array}{l}\text { Sense } \\
\text { of Local } \\
\text { Identity }\end{array}$} & $\begin{array}{l}\text { Academic } \\
\text { Community }\end{array}$ & Homogeneous & Heterogeneous \\
\hline & $\begin{array}{l}\text { Common Long } \\
\text { Term Vision }\end{array}$ & No & No \\
\hline Communication & $\begin{array}{l}\text { Academic Area } \\
\text { Administrative } \\
\text { Areas }\end{array}$ & $\begin{array}{l}\text { Bilingual } \\
\text { Limited }\end{array}$ & $\begin{array}{l}\text { Flexible } \\
\text { Limited }\end{array}$ \\
\hline \multicolumn{4}{|l|}{ Willingness } \\
\hline Planning & $\begin{array}{l}\text { Academic } \\
\text { Leadership } \\
\text { NAFTA and EU }\end{array}$ & $\begin{array}{l}\text { Different } \\
\text { Non- } \\
\text { Comprehensive }\end{array}$ & $\begin{array}{l}\text { Similar } \\
\text { Comprehensive }\end{array}$ \\
\hline Resources & $\begin{array}{l}\text { Joint } \\
\text { Infrastructure }\end{array}$ & INTERNET2 & Buildings \\
\hline Actions & Strengthens & Joint Research & Joint Teaching \\
\hline
\end{tabular}

Finally, in the Paso del Norte and the Oder region CBC between HEIs is a novel process embedded of actions that lack of a long term vision. Academic $\mathrm{CBC}$ is also a process that demands trustworthiness and community support on both regions. Survey results obtained in this research display that the perception among local decision-makers, business groups and community groups in the most developed border cities do not consider that $\mathrm{CBC}$ with HEIs of the less developed partner city will benefit from the progress of the region. In El Paso only $30 \%$ of the sample population considered that such collaboration has been beneficial. In Frankfurt (Oder) only 35\% of the sample population supports such idea. These findings display that in El Paso and Frankfurt (Oder) the community might have more expectations if collaboration is developed with more advanced institutions that might contribute to create more highskilled jobs to the region rather than just support the academic growth of the HEIs on the other side of the border. Research results display the existence of a low culture of CBC among the local population on both border regions. Based on the above, it is possible to argue that HEIs on the Paso del Norte and the Oder region must direct their efforts to mature the process of $\mathrm{CBC}$ before becoming involved in the development of knowledge societies. In these areas, the development of knowledge societies is unattainable if a mutual strategy to achieve this goal at the regional level is not present. This is the natural characteristic of the twin border localities where it is difficult to achieve a 
global goal in one side if the other side of the border is not involved.

\section{ACKNOWLEDGEMENTS}

The research activities for this article were funded by the DAAD (Deutscher Akademischer Austauschdienst) and kindly supported by our colleague Tim Freytag (Universität Freiburg, Germany).

\section{REFERENCES}

ALTBACH, P.; KNIGHT, J. The Internationalization of Higher Education: Motivations and Realities. Journal of Studies in International Education. v. 11, pp. 290-305. (3/4 Fall-Winter), 2007.

ADAM MICKIEWICZ UNIVERSITY POZNAN (AMU), 2010. Available at: www.amu.edu.pl/ www/amu-presentation

BALDAUF, K. The City of Frankfurt (Oder), Germany. Conference OPEN DAYS WS08C27: Second Generation Cross-border Cooperation: New Administrative Structures or Cross-border Cooperation. Frankfurt (Oder), Germany, October 08, 2008.

BATTERBURY, S.; HILL, S. Assessing the Impact of Higher Education on Regional Development: Using a Realistic Approach for Policy Enhancement. Journal of Higher Education Management and Policy. v. 16, n. 3, pp. 35-52, 2004.

BLATTER, J. From "spaces of place" to "spaces of flow"? Territorial and functional governance in cross-border regions in: Europe and North America International Journal of Urban and Regional Research, v. 28, pp. 530-548, 2004.

COLLEGIUM POLONICUM. A Cross-border Academic Institution of the Adam Mickiewicz University Poznan and the European University Viadrina Frankfurt (Oder)-Slubice, Poland: Collegium Polonicum, 2009.

EUROPA VIADRINA UNIVERSITAT ABOUT US: Facts and Figures, http://www.euv-frankfurt-o. de. (2010a).

Brochure: Winter Term 2009-2010, Viadrina Courses offered in English, Spanish, Polish and French. Frankfurt (Oder), Germany, 2010b.
The University in the Heart of Europe, European University Viadrina Frankfurt (Oder). Frankfurt (Oder), Germany, 2008.

EUROREGIONPROEUROPAVIADRINA (2001), Gemeinschaftsinitiative INTERREG (The INTERREG Initiative: Looking Back at the years 1995 to 1999 and prospect for the future, Frankfurt (Oder): Euroregion Pro Europa Viadrina.

GLEISENSTEIN, J. German Head of the Joint Commision for Integration Frankfurt (Oder)-Slubice, Personal Interview at Frankfurt (Oder) City Hall, Frankfurt (Oder), Germany. 20th. January, 2010

GRIX, J. Towards a Theoretical Approach to the Study of Cross-border Cooperation. Perspectives, v. 17, pp. 5-13, 2001.

HemerotecaDigital@Juarez. Un marco de planeación regional para las Universidades Juárez - El Paso - Las Cruces. Available in: http:// www.arrobajuarez.com/busca.php?pageNum busca $=14 \&$ palabra $=$ uach\&totalRows_busca $=164$.

INTERNET2Cases (2005). United States-Mexico Dark Fiber Link UTEP and UACJ. Available in: http://www.internet2.edu/pastshowcases

KLODNICKI, M. Vice-Director for Administrative Affairs Collegium Polonicum, Personal Interview at Collegium Polonicum, Slubice, Poland, 2010.

KRÄTKE, S. Cross-border Cooperation and Regional Development in the German-Polish Border Area. In: M. Perkmand and Ngai-Ling Sum (eds.), Globalization, Regionalization and Cross-border Regions, Palgrave Mcmillan, London, pp. 125-147, 2002.

LEIBENATH, M. Europeanisation of Cross-border Governance? A Case Study on the Cause, Form and Consequences of a Co-operation Project in the German-Polish-Czech Border Triangle. Space and Polity. v. 1, n. 2, pp. 151-167, 2007.

LLERA, F. Diagnóstico v Consideraciones Generales sobre el establecimiento de un Centro de Investigación en Ciudad Juárez a través de la Colaboración UACJ/UACH/UNAM/GOB.EDO. CHIH. internal document UACJ-DGIC, 2001.

MARTINEZ, O. Border people: Life and Society in the US / Mexico. University of Arizona Press, Tucson, 1994.

PROMEP-UACJ. Boletín Estadístico PROMEP-UACJ, n. 3, Oficina PROMEP-UACJ, 2004. 
SCHUNOW, B. Coordinator of Incoming Students, Office of International Programs and Exchange Students, Europa Viadrina Universitat, Personal Interview at Europa Viadrina Universitat, Frankfurt (Oder), Germany, February 4th, 2010.

UACJ, Universidad Autónoma de Ciudad Juárez, in Pregrado / Posgrado: Available in: http:// www.uacj.mx/paginas/posgrado, 2010.

UACJ-DGIC. Base de Datos de Proyectos de Investigación con Financiamiento Externo, Juárez, Mexico, 2006.

UTEP, University of Texas at El Paso, in About UTEP: FACTS/ ACADEMIC PROGRAMS 2010. Available in: http://www.admin.utep.edu

WOJCIECHOWSKI, K. Director of the Collegium Polonicum, Personal Interview. Collegium Polonicum, Slubice,Poland, January 18, 2010.

. Gedanken zur grenzuberschreitenden universitaren Zusammenarbeit in Europa, In BIELAWSKA, A.; WOJCIECHOWSKI, K. (eds.), Europaischer Anspruch und regionale Aspekte. Grenzuberschreitende universitare Zusammenarbeit in der deutsch-polnischen Grenzregion angesichts der zukunftigen Herausforderungen in Europa, Logos, Berlin, pp. 9-24, 2007a.

“Tops and Flops. The Collegium Polonicum as a Cross-border University", paper presented at the Meeting of the Association for Borderland Studies within the Panel of Legal Issues in Borderland Relations, WSSA, Calgary, April.11-14, 2007b.

Recebido em: 07/06/11 Aceito em: 09/07/11 